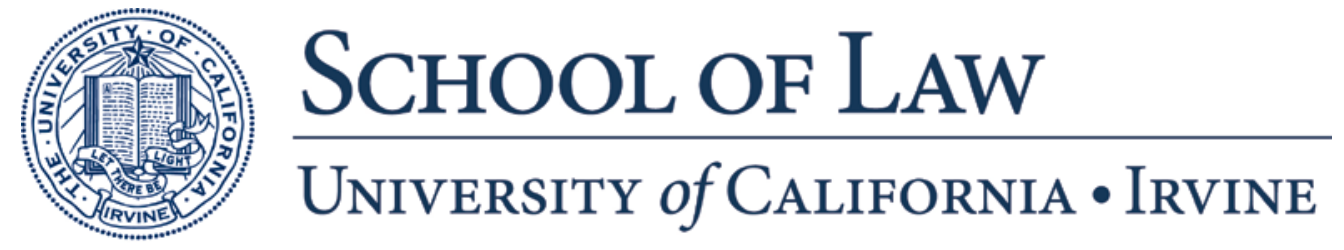

Legal Studies Research Paper Series No. 2012-77

\title{
Intellectual Property in the Cathedral
}

\author{
Dan L. Burk \\ dburk@law.uci.edu \\ University of California, Irvine School of Law
}

The paper can be downloaded free of charge from SSRN at: 


\title{
Intellectual Property in the Cathedral ${ }^{*}$
}

\author{
Dan L. Burk ${ }^{\dagger}$
}

\section{Introduction}

In this chapter I propose to explore a number of ramifications of the entitlement structure chosen for intellectual property. Reto Hilty ${ }^{1}$, echoing theoretical work by Jerry Reichman ${ }^{2}$ and others, has called for greater use of the compulsory license in intellectual property systems, a call with which I concur. Indeed, my only point of disagreement will be that this call is not enough. My argument will be that liability rules such as the compulsory license are indeed appropriate in many more instances than we have tended to employ them, but that even this recognition is too timid. Property theory provides us with a range of possible entitlement constructions, including the classic property rule and liability rule, but by no means limited to these. I will suggest that not only liability rules, but several other kinds of related allocation rules, ought to be more routinely used in intellectual property cases than they have been. While many of my examples will be drawn from common law remedies, the structure is equally applicable to incorporation within civil codes, and as I will suggest, administrative process as well.

\section{Exploring the Cathedral}

Our exploration of possible entitlement structures begins with the famous Calabresi and Melamed article on Property Rules, Liability Rules, and Inalienability: One View of the Cathedral. $^{3}$ This work has been largely responsible for establishing and defining these terms of property and liability. Following the Calabresi/Melamed framework, we typically speak of property rules as conferring on their holders a right to exclude, and liability rules as conferring on their holders a right to be paid. When speaking of intellectual property as property, we tend to assume that the entitlement to the subject matter of patent, copyright, trademark and similar regimes paradigmatically involves the right to exclude. However, liability rules are not unknown

\footnotetext{
* Copyright 2012 by Dan L. Burk. Excerpted from ACCess Challenges IN The $21^{\text {ST }}$ Century (Dana Beldiman et al. eds., forthcoming 2013).

${ }^{\dagger}$ Chancellor's Professor of Law, University of California, Irvine. I thank Reto Hilty, Dana Beldiman, and participants in the Bucerius Law School conference on “Access Challenges in the $21^{\text {st }}$ Century” for their comments on a previous version of these ideas.

${ }^{1}$ See, e.g., Reto Hilty, Licensing for Innovation, Competition, and Creation in INTELLECTUAL PROPERTY AND InNOVATION: A FRAMEWORK FOR 21 $1^{\text {st }}$ CENTURY GROWTH 48 (Ian Hargreaves \& Paul Hofheinz, eds., 2012).

${ }^{2}$ See, e.g., Jerome H. Reichman, Of Green Tulips and Legal Kudzu: Repackaging Rights in Subpatentable Innovation, 53 VAND. L. REV. 1743 (2000).

${ }^{3}$ Guido Calabresi \& A. Douglas Melamed, Property Rules, Liability Rules, and Inalienability: One View of the Cathedral, 85 HARV. L. REV. 1089 (1972).
} 
to such regimes. ${ }^{4}$ It may be that they should be more common, and if we are serious about considering the Calabresi/Melamed framework, there are perhaps other rules worth considering as well.

Calabresi and Melamed were of course speaking generally about almost any system of entitlement, but here we will focus on the context of an intellectual property entitlement, such as a patent. We might begin by considering how, when a patent or similar intellectual property entitlement is disputed, the remedies available to a court adjudicating the dispute could be structured to treat the entitlement under any of four allocative rules. Under the Calabresi/Melamed framework, we could characterize the court's choices as encompassing two possible reciprocal property rules and two possible reciprocal liability rules, allocating one of each possible rule to the prevailing party:

Rule 1: the court could find infringement and enjoin the infringing activity.

Rule 2: the court could find infringement but allow the infringer to continue if he pays damages to the intellectual property holder.

Rule 3: the court could find no infringement and allow the alleged infringer's activity to continue without paying damages.

Rule 4: the court could find infringement but allow the infringer to continue unless the intellectual property owner pays damages to the infringer in order to enjoin the infringing activity.

Following work by Ian Ayres ${ }^{5}$, we can arrange these entitlement rules into a two by two matrix, distinguishing them on the one dimension by who holds the entitlement, and on a perpendicular axis by the type of entitlement: property or liability. Looking at the first column, in the case of intellectual property, such as a patent, either the patent holder or the alleged infringer may have the right to use the subject matter of the entitlement, such as a claimed invention. If the rule allocates this right to the patent holder, she will be able to prevail on a court to enforce the right by means of an injunction. But if the alleged infringer can show either non-infringement or validity, he by default holds the right to continue his activities.

The purported advantage of property rules is that they harness private information to optimize uses of assets such as intellectual property. Under conditions of low transactions costs, we expect that wherever the exclusive right is allocated, the parties will negotiate for the right so that whichever party values it the most will pay the other to secure the right. This moves the right to its highest value use, nicely aligning private preferences with public welfare. Indeed, under sufficiently low transaction costs, we don't care who is given the right initially; bargaining will move it to whichever party values it the most. This is the optimal outcome that free market

\footnotetext{
4 See Dan L. Burk, Muddy Rules for Cyberspace, 21 CARDOZO L. REV. 121 (1999).

${ }^{5}$ Ian Ayres, Protecting Property with Puts, 32 VAL. U. L. REV. 793 (1998); see also IAN AYRES, OPTIONAL LAW:

THE STRUCTURE OF LEGAL ENTITLEMENTS (2005) (discussing options structures in property remedies).
} 
economists, and many naïve law professors, hope and expect will occur under the famous Coase theorem. ${ }^{6}$

But Coase's point in fact was that this condition of low transaction costs is seldom the case; markets are costly mechanisms for exchange, and transaction costs will frequently impede the reallocation of the right. And, since our information about optimal outcomes is always imperfect, we should expect that the right will frequently be placed into the wrong hands, and could very likely become lodged there. It therefore behooves us to expend some resources to get the allocation correct in the first instance, since an improper provision may not be selfcorrecting.

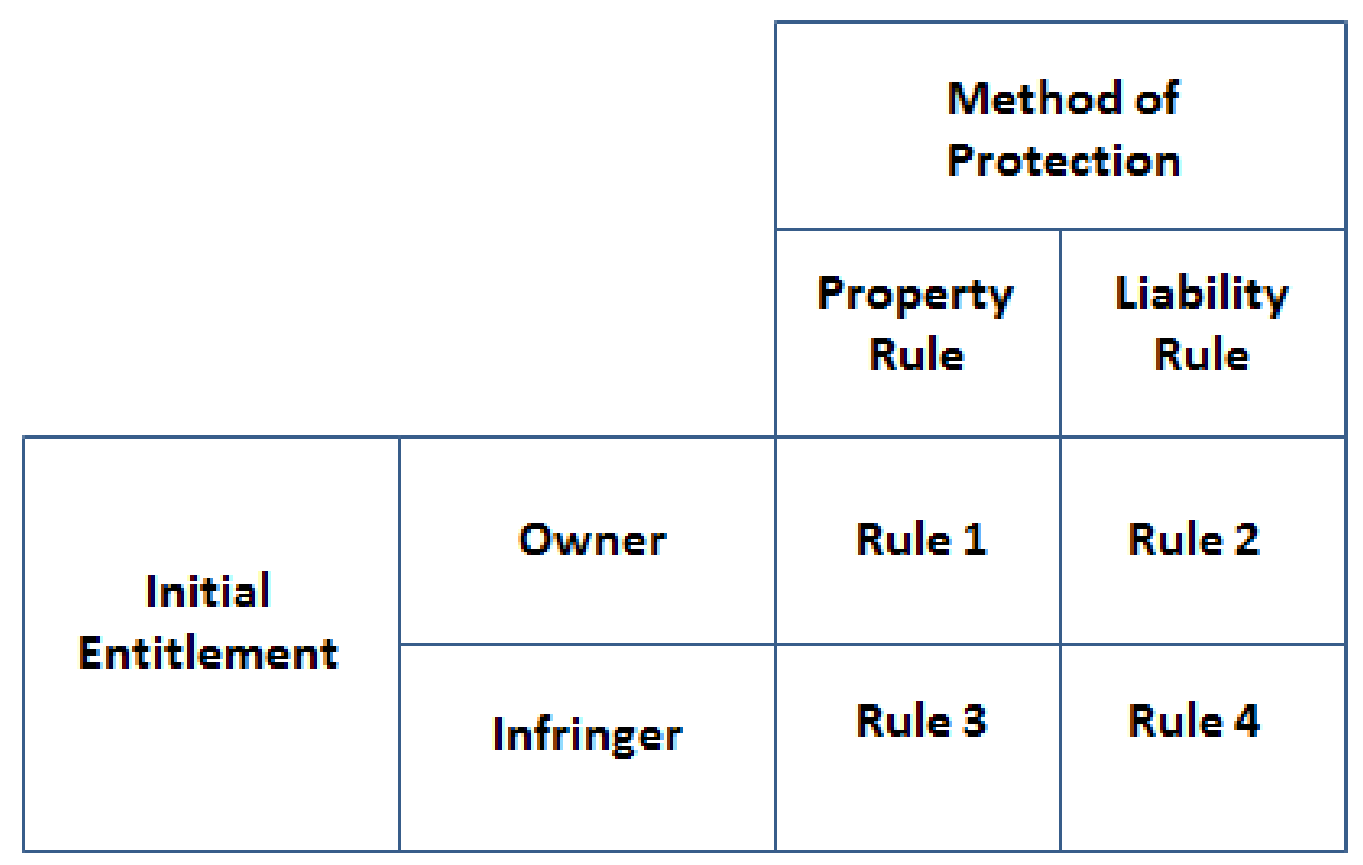

However, another possibility besides property is also available. Looking to the second column, the intellectual property holder may be granted a different remedy, a right to be paid under a liability rule, such as occurs under a compulsory license. Note that sometimes we may couch this in slightly different terms; we may give the alleged infringer an affirmative right to continue his activities, as in the case of prior user rights. That might be characterized as giving the alleged infringer a Rule 3 property right to continue his activities, but is also effectively a Rule 2 compulsory license at a zero royalty - which should remind us that these rules sometimes blend together at the edges, and so the labels we give them are not always crisp and clean.

\footnotetext{
${ }^{6}$ See Ronald Coase, The Problem of Social Cost, 3 J. L. ECON. 1 (1960).
} 
Free market enthusiasts worry about liability rules as remedies, because in actual practice information is imperfect and so someone with imperfect information has to set the rate for the liability payment. ${ }^{7}$ A judge or other adjudicator may not set the optimal payment, if that is defined as the payment that the parties might independently negotiate. But if the transaction costs to negotiation are high, as we have said, the parties may never reach any agreement, optimal or otherwise. In cases of high transaction costs, many commentators believe that a imperfectly calibrated payment may be a better solution than an immovably lodged property right.

\section{Considering Reverse Liability}

However, this does not yet complete our two by two matrix. There is yet an additional possibility in the liability column, a fourth possible rule. We have considered the possibility of bestowing a property right on each of the parties, and symmetry suggests that we should do the same for liability rules. Notice that, as in the case of the property rule, it is equally possible to assign a reciprocal right to be paid to the alleged infringer rather than to the entitlement holder. We might call this a reverse liability rule, to distinguish it from the Rule 2 under which the entitlement holder has a right to be paid. Under Rule 4, the alleged infringer might have a right to be paid.

American lawyers will recognize this rule as the famous "reverse liability rule" from the

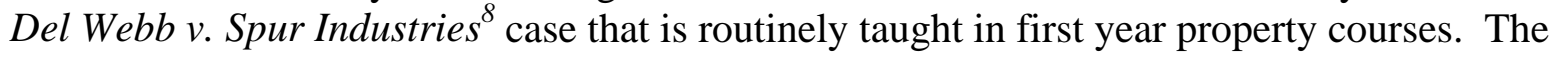
Spur Industries case involved a land developer of residential homes who built houses near a cattle feed lot. Because the feed lot generated dust and offensive smells that affected the residential housing, the developer sued to abate the nuisance -- essentially, asked the court for an injunction to close or move the feed lot. The court hearing the case could have chosen Rules 1 or 2 -- that is, could have assigned a property right to one of the parties, either saying that the feed lot had a right to produce dust and odor, and so denied the injunction, or in the alternative could have said that the home owners had a right to be free from dust and odor, and so granted the injunction.

The court instead fashioned a different remedy. It held that the residential developer was entitled to an injunction, with a caveat. Since the developer had in some sense "come to the nuisance," putting himself and his purchasers in a position to be affected by the feed lot dust and smell, the court held that the feed lot should not bear the cost of the move. The developer's injunction would be contingent on a payment to the feed lot owner to offset the cost of moving his operation. In our application of the rule to intellectual property, we would map the developer and the feed lot onto the patent holder and the infringer. Rather than the entitlement owner such as a patent holder -- receiving a payment from the alleged infringer, instead the infringer

\footnotetext{
${ }^{7}$ See, e.g., Robert P. Merges, Contracting into Liability Rules: Intellectual Property Rights and Collective Rights Organizations, 84 CAL. L. REv. 1293 (1996); but see Mark A. Lemley, Contracting Around Liability Rules 100

CAL. L. REV. 463 (2012) (cataloging examples of how parties use liability regimes as a starting point for negotiations).

8108 Ariz. 178, 494 P.2d 700 (1972).
} 
would be entitled to receive the payment if the entitlement owner elects to exercise her exclusive rights.

\section{Reverse Liability in Intellectual Property}

There has been little consideration as to how such a rule might play out in intellectual property, rather than real property. But one can quickly see possible applications. One of the major controversies currently surrounding patent law, especially in the United States, is the problem of non-practicing entities (NPEs) or so-called patent trolls. ${ }^{9}$ It is difficult to determine exactly who is a patent troll -- sometimes it seems to be any patent owner that someone else doesn't like, but they are typically characterized as firms that have acquired a patent, or sometimes an entire portfolio of patents, not in order to produce an innovative product, but only to enforce or threaten to enforce the patent to generate a revenue scheme. Sometimes the patents are obscure, or likely to be found invalid if someone was willing to spend the money to challenge them. Typically the "NPE" firms have no research or production capacity, so the concern seems to be that the patents are not facilitating innovation, but only a kind of rent-seeking.

The concern is that a property rule, awarding exclusive rights through the mechanism of an injunction, gives the "troll" too much leverage. Because the injunction can completely shut down the infringing party's operations if they are reliant on the patented technology, the injunctive threat can be equal to the value of their entire business. In the United States, this concern was partially addressed by the United States Supreme Court decision in eBay vs. Merc Exchange. ${ }^{10}$ Prior to this decision, there had been a lower court presumption in favor of an almost automatic permanent injunction for patent owners who proved their cases against infringers, on the theory that the right to exclude via an injunction is the essential characteristic of a property right. However, the Supreme Court pointed out that the patent statute authorized issuance of an injunction on equitable grounds, and a court sitting in equity should consider the public interest, the adequacy of a legal remedy awarding damages, and the relative hardship of an injunction on the two parties.

There is empirical evidence that since the eBay decision, the injunctions granted to NPE patent holders has dropped, while maintaining the availability of injunctions for manufacturing or active research firms. ${ }^{11}$ This equitable balancing test is effective in separating innovative patent holders from those who are seeking only revenue -- in other words, from non-practicing entities. NPEs who are seeking only to generate a revenue stream are adequately compensated by damages after a successful law suit, meaning that the injunctive remedy is unnecessary and perhaps harmful. However, a patent holder who is interested in producing a product, and so needs exclusivity to clear or structure his market, would likely not be adequately served by monetary damages, and so should receive the injunction. The rule in effect substitutes a compulsory license in those cases where the public interest and the balance of the equities militates against a strict property rule

\footnotetext{
9 Michael Risch, Patent Troll Myths, 42 Seton Hall L. ReV. 457 (2012).

10547 U.S. 388 (2006).

11 See Colleen Chien \& Mark Lemley, Patent Holdup, the ITC, and the Public Interest, 98 CORNELL L. REV. (forthcoming 2012).
} 
The use of a liability rule in this instance seems to have been fairly successful. But a reverse liability rule might be even more successful in dealing with the NPE leverage problem. Instead of the eBay compulsory licensing liability rule, imagine the application of the Spur Industries rule: a court sitting in equity might say to the patent holder, you are welcome to your injunction if you are willing to pay the cost that will be imposed on the infringer by adopting the next best technological alternative. This removes the threat of shutdown from negotiations over the patented technology, as well as any advantage that might come from ambushing competitors who had unwittingly adopted a patented technology.

One might be concerned that the rule could create an incentive to infringe, as the worst that could happen would be a subsidized change to the next best alternative technology if caught. But the answer to this objection is that, in balancing the equities of a case, the rule should only be deployed where there is evidence of innocent infringement on the one hand, or of ambush or untoward bargaining leverage on the other. These are the kinds of criteria we use in deciding whether the eBay rule should apply, and can equally well be used to help decide whether a reverse liability rule is appropriate.

Then why not simply use the $e$ Bay rule; why add another possible outcome to patent litigation, which some feel is already overly uncertain and expensive? The answer is that another tool in the court's kit of remedies allows it to better tailor outcomes to specific situations. In particular, the reverse liability rule at least partially answers the objection that liability rules are potentially inefficient because they impose a price set by an adjudicator who has imperfect valuation information. The Spur Industries rule at least partially harnesses private valuation by putting the patent holder back in the driver's seat. The patent holder is given the choice whether to pay the cost of the injunction or not; if the injunction is not worth the cost he can forgo it. The rule therefore serves to separate the trolls from the innovators: those who really needed exclusivity to establish a market for the product they were producing could assert their property rights, but at a price. Trolls are allowed voluntarily segregate themselves from non-trolls, rather than requiring a court to determine who is an NPE and who isn't.

Note also the corollary change in bargaining position of the alleged infringer. If the intellectual property owner chooses damages, essentially a compulsory license, the infringer may use the damage payment as a starting point for royalty negotiations; this type of bargaining is common in cases of payments imposed by a third party adjudicator. ${ }^{12}$ The effects are even more striking if the intellectual property holder chooses the injunction subject to a payment. The infringer may now wish to negotiate a license, but rather than bargaining from an all or nothing position, as he would be in the case of an injunction under a pure property rule, the infringer is now bargaining from the starting point of receiving a damages payment. Even with the injunction, the intellectual property owner, troll or otherwise, is no longer in the position of holding the infringer up for the entire value of his business. In other words, the valuation and bargaining range of the parties is now much narrower, making an agreement more likely. In situations where the parties' valuations would be very far apart, judicially narrowing the range may facilitate private agreement. ${ }^{13}$

12 See Lemley, supra note 7.

${ }^{13}$ See Burk, supra note 4 at 132. 
Or, as a second example of where to use a reverse liability rule, imagine the application of this rule in the context of controversies over patents in a standard-setting. Interoperation of technological systems frequently requires some type of standardization; indeed, technologies often tend toward a single standard. ${ }^{14}$ This means that there is often a "lock in" effect to technical standards; unless a manufacturer adopts the standard, his product is marginalized. ${ }^{15}$ Access to and adoption of the standard, so that products are compatible with existing systems, becomes essential to effectively compete in the market.

As a corollary, if a manufacturer holds intellectual property rights in a standard, those rights can convey enormous market power. Indeed, adding intellectual property rights on top of a technological standard seems often like piling on too much of a good thing. Because of this, standard-setting organizations typically require disclosure of intellectual property interests by their members when technological standards are being adopted. ${ }^{16}$ Patent owners are typically required to reveal the presence of their patent, and agree that if their technology is adopted as the standard, they will make licenses available on fair, reasonable, and non-discriminatory (FRAND) terms. $^{17}$

There have been some occasions where a patent holder has failed to disclose his proprietary interest in a technical standard, and perhaps has even willfully concealed his proprietary interest until the standard has been adopted and is difficult to alter. Attempts to enforce a patent against alleged infringers, who have adopted the patented standard under the impression that it would be available on FRAND terms, raises difficult claims regarding fraud and misrepresentation. A reverse liability rule seems almost tailor made to such a situation. A court might say to the patent holder, fine, you are entitled to your injunction against those using your technology -- but only if you are willing to pay the costs for those who have adopted the standard and who wish to switch to an alternative. I suspect that this would deter most patent holders from asserting their patents once the patented technology was adopted as a standard. But those who truly wished to assert their exclusivity could do so, at a cost. The cost might be considered an equitable or restitutionary penalty for not dealing openly in the first place.

\section{Considering Calls and Puts}

Rules 2 and 4 have some important characteristics that may not immediately be apparent but that flow from the right to be paid. Under a liability rule, the entitlement holder might prefer to obtain an injunction rather than a payment, but the injunction is not available. This effectively means that the party that takes the asset can decide to do so, knowing that the penalty is to pay a certain price under the liability rule. This entitlement structure closely parallels certain types of financial instruments. Financial economists talk about "call" options, which are contracts that

\footnotetext{
${ }^{14}$ Mark A. Lemley, Antitrust and the Internet Standardization Problem, 28 ConN. L. REV. 1041 (1996).

15 Mark A. Lemley \& David McGowan, Legal Implications of. Network Economic Effects, 86 CAL. L. REv. 479 (1998).

${ }_{17}$ Mark A. Lemley, Intellectual Property Rights andStandard-Setting Organizations, 90 CAL. L. ReV. 1889 (2002).

17 Joseph Scott Miller, Standard Setting, Patents, and Access Lock-In: RAND Licensing and the Theory of the Firm, 40 IND. L. REV. 351 (2006).
} 
specify a certain price, called the exercise price, for future purchase of certain commodities. A call option is in essence the right to buy at a specified price. The holder of the commodity may not want to sell at that price at the time of the purchase, but the contract nonetheless allows the buyer to force the sale at the price at the time he chooses within the terms specified by the contract.

One can quickly see the parallel to a liability rule. ${ }^{18}$ A liability rule, such as a compulsory license, effectively places the choice of whether to force an exchange into the hands of the alleged infringer. The intellectual property holder may not wish to "sell" the rights at the price specified by the compulsory license, but the statute or holding that animates the liability rule leaves no choice: the intellectual property holder is entitled to receive payment, but may not decline to sell. The same is of course true in the reverse liability rule situation; the home builder can purchase the rights to be free of dust and stink at a specified price. The feed lot owner may not want to move, to essentially sell those rights, but has no choice if the developer decides to exercise the option to buy.

If Rules 3 and 4 are equivalent to call options, then the next logical extension of this paradigm is to consider whether we might apply to intellectual property assets a different set of options, complementary and reciprocal to call options, which in finance are called "put" options. If a call option is the right to buy certain commodities at a certain price, then the put option is the right to sell specified commodities at a certain price. The party under a put contract who holds the right can force the other party to buy the asset at the exercise price, even if the other party would prefer currently not to pay that price for the asset.

As in the case of liability "call” options, the put could be allocated to either party in a dispute over an entitlement. In one case, the intellectual property owner could require the infringer to buy the intellectual property, in the other case, the alleged infringer could require the intellectual property owner to pay for exclusion. This gives us two new rules, Rule 5 and Rule 6 .

Rule 5: the alleged infringer continues to use the intellectual property, but can choose to stop infringing and receive damages from the intellectual property owner.

Rule 6: the intellectual property owner can enjoin the infringement, or can choose to waive the injunction and instead collect damages from the infringer.

The addition of "put" rules to the picture adds an additional column to our matrix. Note that the new rules are reciprocal to the previous liability rules. The right is still a right to be paid, but the decision as to whether to force an exchange has been placed in the hands of the other party vis a vis the corresponding liability rule. Here again the hope is to harness the private information of the parties, by placing the choice of remedies into the hands of whichever party is in the best position to make a private valuation that will align with the public interest.

\footnotetext{
${ }^{18}$ Madeline Morris, The Structure of Entitlements, 78 CoRNELL L. Rev. 822, 854-56 (1993); Ian Ayres \& J.M. Balkin, Legal Entitlements as Auctions: Property Rules, Liability Rules, and Beyond, 106 YALE. L.J. 703, 729-33 (1996).
} 


\begin{tabular}{|c|c|c|c|c|}
\hline & & \multicolumn{3}{|c|}{ Method of Protection } \\
\hline & & $\begin{array}{c}\text { Property } \\
\text { Rule }\end{array}$ & $\begin{array}{l}\text { “Call" } \\
\text { Rule }\end{array}$ & $\begin{array}{l}\text { "Put" } \\
\text { Rule }\end{array}$ \\
\hline \multirow{2}{*}{$\begin{array}{c}\text { Initial } \\
\text { Entitlement }\end{array}$} & Owner & Rule 1 & Rule 2 & Rule 6 \\
\hline & Infringer & Rule 3 & Rule 4 & Rule 5 \\
\hline
\end{tabular}

This entitlement structure is relatively rare compared to the other allocations in the table. Property rules are of course well known and well established in law. Liability or "call" type rules are also relatively well known in the law. "Put" type rules are less well known, but can be identified if one knows what to look for. Ayres has identified several examples where this type of rule is employed at common law, allowing an asset holder to essentially force a sale of the particular asset. $^{19}$

So for example, if Hilty steals my toothbrush, at common law, I can elect to sue either for an injunction to force him to return the toothbrush, or alternatively for damages to force him to pay me the value of the toothbrush. ${ }^{20}$ In other words, I have a choice whether to force him to return the item he has taken or to pay me for it. It is fairly easy to see why I might want to have the choice between the two remedies, particularly if I suspect that he may have been using the toothbrush. In that case I may prefer the money over the restoration of the item. But the key point is that I can make the choice, requiring him to in effect buy the item from me if I prefer that outcome.

Similarly, if Hilty and I own adjacent parcels of land, and he builds a wall that extends over my side of the property line, encroaching on my land, I can sue either for an injunction to force him to tear down the wall, or in the alternative, I can sue to force him to pay me the value

19 See Ayres, supra note 4 at 800.

${ }^{20}$ Id. at 815. 
of the land on which the wall is situated. ${ }^{21}$ Again, I have the choice whether to recover the real property or to receive a payment. In effect, I can force him to buy the land on which the wall is situated if I prefer that outcome to recovering the land.

\section{Advantages of Divided Entitlements}

These type of asset allocations effectively create divided entitlements to the asset. Property rights as traditionally formulated under Rules 1 and 2 are largely binary: one party receives the entire allocation, the other party receives nothing. But under call and put type allocations, each party receives something: either the right to possession of the asset, or the right to alienate the asset and receive a payment. ${ }^{22}$ Giving each party a stake in the outcome, and allowing the party with the most valuation information to choose the allocation of the respective rights, tends to move the property to its best use in light of the events that have engendered the cause of action. This also helps ameliorate the problems associated with bilateral monopolies. Bilateral monopolies are known for producing a negotiating stand-off, where each party may try to hold out for the full value of the entitlement. Dividing entitlements ensures that the fortunes of the parties are tied together by the overlapping value of the shared entitlements, giving them an incentive to move past a stand-off. ${ }^{23}$

This can be seen in familiar intellectual property allocations. Despite all the discussion about patents and other intellectual property as strong, presumably unitary property rules, divided entitlements are by no means unknown in intellectual property. ${ }^{24}$ Perhaps the best known example is found in the doctrine of blocking patents where one party may hold a patent covering a class of innovations, and another follow-on improver may simultaneously hold a patent covering a specific improvement or sub-class covered by the broader patent. Such improvers are effectively in a situation of bilateral monopoly; neither can exploit that particular improvement without coming to terms with the other. This effectively divides the value of the improvement between the two patent holders, and ensures that improvers always have some incentive to develop existing technologies. ${ }^{25}$

Put- type options may be appropriate where an election might help to deter counterproductive or in terrorem use of intellectual property rights. For example, imagine that Hilty develops and markets an improvement to an existing widget. The holder of a patent to such widgets sues Hilty, perhaps even obtaining a preliminary injunction against marketing the improvement. Hilty ultimately prevails at trial, showing either that the underlying patent is invalid or uninfringed - but by now the market opportunity for the device has passed, and even though he is free to use the widget, all the latest models of the device use some other type of widget. If given the Rule 5 option, Hilty might prefer to waive the right to continue using the widget and instead collect damages from the patent owner for the sales that he would have made had he been left in peace - in effect, forcing the patent owner to buy the improvement. In fact,

21 Id

${ }^{22}$ Carol Rose, The Shadow of the Cathedral, 106 YALE L. REV. 2175 (1997).

${ }^{23} \mathrm{Id}$.

${ }^{24}$ See Burk, supra note 3 at 142-43.

${ }^{25}$ Mark A. Lemley, The Economics of Improvement in Intellectual Property Law, 75 TEXAS L. REV. 989 (1997). 
under such circumstances, something like Rule 5 helps cure a version of the patent "troll" problem.

Such "put" type option structures can also be seen in some types of administrative programs. For example, this type of option is effectively built in to government programs to buy back guns or to exchange dirty needles. ${ }^{26}$ Possessors of these items can in effect demand a payment for a gun, or a new needle in exchange for an old needle. Such programs are intended to get either guns or needles off the streets. We might ask ourselves whether put options could equally well be used to get bad patents off the streets.

Our current method for getting bad patents off the streets involves a type of call option: patent owners pay periodic maintenance fees to continue their period of exclusivity. ${ }^{27}$ A patent owner who decides not to pay the fee ends the patent term early -- in other words, patent owners can opt to buy additional increments of time on the patent. This is in essence a call option, the right to buy additional time at a fixed price. A patent owner who decides that the patent is not valuable enough to warrant the payment can allow the patent to lapse, taking the patent "off the street."

Now imagine a different system, built around a put option. Under such a system, an issued patent would be accompanied not by an option to purchase additional time, but by an option to force the issuing authority -- the patent office -- to buy back the patent at a fixed price. Some thought would need to go into setting the exact exercise price for the put, but I would imagine that the price should be something less than the average cost of obtaining a patent, or perhaps it would be some percentage, say $90 \%$ of the actual cost of obtaining the particular patent in question. Suppose, just to pick a number, that the exercise price is set at 5000 Euros. Now the patent owner knows that at any time she can assert the option to have the patent bought back at 5000 Euros. If she estimates that the patent is worth at least 5000 Euros, she will keep it; if she estimates it is worth less to her, she will sell it back. This removes patents that are impractical or uninteresting or otherwise likely to be unworked.

This type of system may have additional advantages besides removing derelict patents from the marketplace. An additional feature of a put-type option is the extra value that attaches to the particular asset. The asset owner has not only the primary asset, but also the value of the put -- indeed, under the right circumstances, the two can be monetized and traded separately; the put itself can become a separate asset. ${ }^{28}$

In the case of intellectual property, where we frequently purport to create entitlements as an incentive to invest in innovative or creative activity, the addition of a put to the underlying entitlement may have interesting benefits. Because the put adds additional value to an entitlement such as a patent, the owner may be willing to invest more. ${ }^{29}$ Additionally, attaching a put to the basic entitlement places a definite and non-speculative asset into the hands of the

\footnotetext{
${ }^{26}$ See Morris, supra note 14 at 855.

${ }^{27}$ Michael W. Carroll, One for All: The Problem of Uniformity Cost in Intellectual Property Law, 55 AM. U.L. REV. 845, 880 (2006).

${ }^{28}$ See Ayres, supra note 4 at 805.

${ }^{29}$ Id. at 800 .
} 
patent owner. She always knows the patent is worth at least 5000 Euros. This may be helpful in attracting outside investment. A portfolio of such patent puts could be advantageous in fostering innovative start-ups and entrepreneurial initiatives. Indeed, the put need not be attached to patents across the board, but might be confined to desirable industries that are particularly risky or where it is difficult to attract investment.

\section{Conclusion}

I should be clear that I am not necessarily endorsing issuing patents subject to a put, or even giving an alleged infringer who prevails at trial a damages remedy. Neither am I necessarily endorsing reverse liability for non-practicing entities, although all these options seem to me worth exploring. And this is of course precisely what I am endorsing: that we begin looking for scenarios where alternative entitlement structures could be put to use. I have confined myself here to a few examples involving patents, but the range of inquiry of course ought to include other form of intellectual property such as copyright, trademark, trade secrecy and industrial design. The range of diversity in intellectual property guarantees a variety of situations in which alternative entitlement structures might be beneficial.

As Hilty and others have demonstrated, confining ourselves to exclusory rights is simply not enough. Perhaps the most common trope regarding intellectual property is that it is property, like real property, and should be treated as such. ${ }^{30}$ Unfortunately, this usually means treating it according to a very narrow ideological approach to exclusivity. Taking the rhetoric about "property” at face value, I hold that we should rather open intellectual property to the full range of entitlement structures that have evolved to accommodate myriad different asset allocations. ${ }^{31}$ I have shown in other work with Mark Lemley that technology is diverse, the innovation profiles of different industries are diverse, and that only a panoply of diverse incentive mechanisms can be expected to foster innovation in these many different environments. ${ }^{32}$ Greater attention to compulsory licenses and related allocative rules adds to the kit of legal tools available to accomplish such goals.

\footnotetext{
${ }^{30}$ See, e.g., Frank Easterbrook, Intellectual Property is Still Property, 13 HARV. J. L. \& PUB. POL’Y 108 (1990).

${ }^{31}$ See Burk, supra note 3 at 126.

32 See Dan L. Burk \& Mark A. Lemley, The Patent Crisis and How The Courts Can Solve It (2009).
} 